Journal of Educational Research in Developing Areas (JEREDA)

Vol. 2. Issue 2, Pp. 164-172, 2021

http://www.jeredajournal.com

E-mail: info@jeredajournal.com

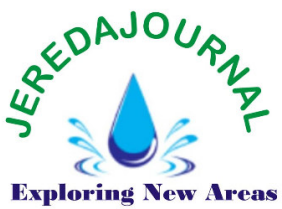

Research Article DOI:https://doi.org/10.47434/JEREDA. eISSN:2735-9107

\title{
EFFECT OF GENDER AND BODY MASS INDEX ON ACADEMIC PERFORMANCE OF JUNIOR SECONDARY STUDENTS IN OWERRI EDUCATION ZONE, IMO STATE, NIGERIA
}

\section{${ }^{1}$ Chinyere Ofoego, ${ }^{2} *$ Ifeoma Ukogo, ${ }^{3}$ Ada Chinaka, ${ }^{4}$ Esther Nwaeze, ${ }^{5}$ Hannah Chukwu}

\author{
${ }^{1}$ Department of Educational Foundation, ${ }^{* 2,4}$ Department of Integrated Science, \\ ${ }^{3}$ Department of Biology, \\ 1,2,3,4Alvan Ikoku Federal College of Education, Owerri, Nigeria. \\ Email: ${ }^{1}$ ofoegochinyere@gmail.com; ${ }^{3}$ adaachinaka@gmail.com; ${ }^{4}$ uru4lcm@gmail.com, \\ chukwuhannahuk@gmail.com \\ ${ }^{2 *}$ Corresponding author:ifykogos@gmail.com@https://orcid.org/0000-0002-8211-6415
}

Received: $10^{\text {th }}$ August, 2021; Revised: $20^{\text {th }}$ August, 2021; Accepted: $05^{\text {th }}$ September, 2021

\begin{abstract}
Introduction: Academic performance of a student is most commonly linked with several factors such as family socio-economic status etc. The nutritional status of a child is an important factor in the development of a child, including mental and cognitive development.

Purpose: This study investigated the effect of gender and BMI on academic performance of Junior Secondary School students in Owerri Education zone, with the aim of comparing the academic achievement of both genders with their BMI.

Methodology: Two research questions and two hypotheses were formulated in order to achieve the objectives. A descriptive survey research design was adopted for the study. The population of the study comprised 23, 229J.S.S students, with sample size of 120 JSS 3 students; 60 males and 60 females, selected by means of simple random sampling technique from 10 schools in the zone. The instruments used for data collection were structured students Test Questions (SSTQ) and school-based result for the last term in English, Mathematics, and Basic Science. Height and weight were recorded to calculate the Body Mass Index (BMI).

Result: The findings of the study showed that: Gender has no significant effect on academic performance of students while BMI has significant effect on academic performance of students.

Recommendation: It was recommended that underweight students should be counseled on how to improve their weight so as to avoid dropping down to severe underweight, as it may affect the brain's ability to process information. This can affect the student's academic performance.
\end{abstract}

Keywords: Academic achievement, School outcome, Normal weight, Obese, Underweight.

Cite paper as:

Crossref Ofoego, C., Ukogo, I., Chinaka, A. A., Nwaeze, E. U. C., \& Chukwu H. N. Cited-by (2021). Effect of gender and body mass index on academic performance of junior secondary students in Owerri education zone, Imo state, Nigeria. Journal of Educational Research in Developing Areas, 2(2), 164172. https://doi.org/10.47434/JEREDA.2.2.2021.164.

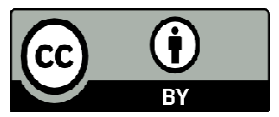

Copyright (c) 2021 The author(s) of this article retain(s) the copyright. 
Journal of Educational Research in Developing Areas (JEREDA)

Vol. 2. Issue 2, Pp. 164-172, 2021

http://www.jeredajournal.com

E-mail: info@jeredajournal.com

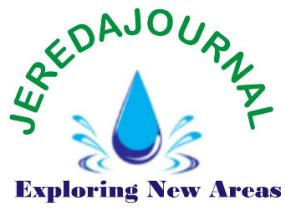

\section{PUBLIC INTEREST STATEMENT}

The result of this study will be of immense benefit to several people such as parents and teachers. The result will enlighten parents on the possible effect of BMI on their children's academic performance. This will enable them take proper care of their children's nutritional needs. Teachers will be educated on the relationship between BMI and school outcome, thereby helping them understand their students' performance.

\section{INTRODUCTION}

Development of any Nation or Community depends largely on the quality of education because the society and education are interrelated and interdependent, therefore education is very vital in human existence. Formal education remains the vehicle for socioeconomic development and social mobilization in any society. A person's education is closely linked to his life chances, income and well-being, (Yadav \& Choubey, 2014). Therefore, it is important to have a clear understanding of what benefits or hinders one's educational attainment. Academic performance is most commonly linked to several topical areas like Gender, Body Mass Index (BMI), Socio-economic status, parental Involvement, family size and so on. Gender is the state of being male or female in relation to the social and cultural roles that are considered appropriate for men and women. It is a socially ascribed attribute which differentiates feminine from masculine. Dike (2018) indicated that gender is a contemporary universal phenomenon.

The difference in gender has cause much concern to educators. Some researchers have reported gender differences, while others have it that there are no significant differences in male-female achievements in cognitive styles, (Onyekwere, Okezie, Ezeribe \& Unamba, 2018). To mention but a few, Ndirika (2013), in his study on investigating gender disparity in science enrolment and achievement in Abia State; Aniodoh and Eze (2014) in their work on enhancing girls' participation in Science through feminist pedagogical techniques, reported that boys perform better in field dependent subjects. Other studies like Nwaiwu and Audu (2005); Lorchugh, (2006) found no significant differences among gender in academic achievement. Unamba, Onyekwere and

Ihekwaba (2015) found no significant differences in gender achievement using an activity-based learning strategy. Also Onyekwere, et al. (2018), found that there is significant difference between male and female field dependent and independent students in mathematics.

Body Mass Index (BMI) otherwise known as Quetelet Index was developed by Adolf Quetelet, a Belgian Mathematician and a scientist between 1839 and 1850. The BMI expressed as $\mathrm{kg} / \mathrm{m}^{2}$ is an individual's body weight divided by the square of the person's height. BMI is a numerical measure of a person's body "thinness or thickness" (Wehigal and Oshaani, 2017). BMI quantifies the amount of tissue mass (bone fat and muscle) in an individual and is used to identify whether the person is underweight, overweight or of normal weight/healthy weight. A person whose BMI is outside the healthy range may have a significantly increased health risk. The BMI ranges include; $<18.5 \mathrm{~kg} / \mathrm{m}^{2}$ classified as underweight, $18.5-24.99 \mathrm{~kg} / \mathrm{m}^{2}$ normal weight, $25-$ $29.99 \mathrm{~kg} / \mathrm{m}^{2}$ overweight, $730 \mathrm{~kg} / \mathrm{m}^{2}$ obese and $\geq 40$ morbidly obese (Gray and Fujioka, 1991). Obese and underweight students are both educationally and socially disadvantaged. They do not do well academically, also it leads to emotional and mental problems like depression and anxiety (Yadav and Choubey, 2014). They also reported that the academic achievement of adolescent girls whose BMI is in the normal range was significantly higher compared to the academic achievement of students who are under or over weight, respectively. Also Suleiman, Eze and Karimah (2017) indicated that there was no association between BMI and academic performance.

Yadav and Choubey (2014) viewed academic performance test as an attempt to measure what has been 
Journal of Educational Research in Developing Areas (JEREDA)

Vol. 2. Issue 2, Pp. 164-172, 2021

http://www.jeredajournal.com

E-mail: info@jeredajournal.com

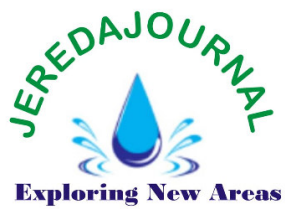

accomplished by the students in various courses of studies. This is usually measured in percentage (\%) of the marks obtained in the various subjects in different examinations. The overall scores are then taken as indicators of the student's achievement.Simpson and Weiner (1989) defined performance as the observable or measurable behavior of a person, an animal in a particular situation, usually experimental. By this definition, performance measures behavioural aspects that can be observed at a specific period. A performance test is usually used to determine performance. Academic performance can be regarded as the observable and measurable behavior of a student in a particular situation, (Akuezuilo, 1997). Academic performance can also be said to consist of all the scores of the students obtained from teacher-made test, term examination and tests. Academic performance is a part of educational growth.

An important aspect of the modern educational system is to find the effectiveness and efficiency of teaching. This is achieved with the help of a good teaching method and evaluation system. The present-day educational institution has therefore devised examination with the sole purpose of measuring the performance of students. The performance is influenced by a variety of social and psychological factors. In this study, an effort is made to investigate the effect of gender and BMI on the academic performance of students.

\section{STATEMENT OF THE PROBLEM}

A successful schooling outcome for all students is important for the economic growth of any nation. International ranking shows that Africa in general and Nigeria inclusive is well behind in world ranking in Science, Reading and Mathematics (OECD, 2010). Educational objectives are made up of academic standards for what students should know and be able to do at the end of any educational activity.

There has been increased consideration for the health and general well-being of man and the knowledge of

the importance of maintaining a healthy life in all areas of life. The impact of global development and advancement in technology has not only bettered the economy and made life more comfortable, but on the contrary has gone the extra mile to bring changes in dietary habits and nutritional lifestyle. Thus, placing individual's BMI at an unhealthy scale, which in turn has negatively affected one's general wellbeing. Fitness issues such as nutrition, physical fitness, healthy lifestyles, etc. are on the front burner of global health discourse. Awareness of obesity, malnutrition and their risk factors, as well as strategies for the reduction of obesity, are also front-line topics. Studies such as that of Sumerall, (2014) have shown a link between physical health and academic achievement,

There has been an increase in malnourished children (owing to the current recession) and overweight children (from poor nutritional outcomes) in Nigeria. These children experience the physical and emotional consequences of being either overweight or underweight, which may be related to their school performance. Garcy (2009) pointed out that there is a connection between body weight and academic achievement. Therefore, it is imperative to examine the gender and health factors (BMI) that may be associated with academic success of students.

\section{PURPOSE OF THE STUDY}

The general purpose of the study is to investigate the effect of gender and BMI on academic performance of Junior Secondary School (JSS) students in Owerri educational zone of Imo state. Specifically, the study aims at;

1. To find the mean academic achievement scores of male and female students in English, Mathematics and Basic Science in Owerri education zone.

2. To examine if there is any difference in the mean academic achievement scores of the students based on their BMI Index 
Journal of Educational Research in Developing Areas (JEREDA)

Vol. 2. Issue 2, Pp. 164-172, 2021

http://www.jeredajournal.com

E-mail: info@jeredajournal.com

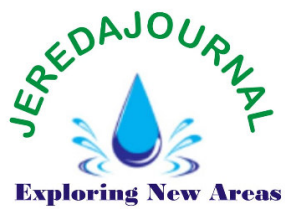

in English, Mathematics and Basic Science in Owerri education zone.

\section{RESEARCH QUESTIONS}

1. What is the difference in the mean academic achievement score of male and female students in English, Mathematics and Basic Science in Owerri education zone?

2. What is the difference in the mean academic achievement scores of students based on their BMI Index in English, Mathematics and Basic Science in Owerri education zone?

\section{HYPOTHESES}

1. There is no significant difference in the mean academic achievement scores of male and female students in English, Mathematics and Basic Science in Owerri education zone.

2. There is no significant difference in the mean academic achievement scores of students based on their BMI Index in English, Mathematics and Basic Science in Owerri education zone.

\section{METHODOLOGY \\ Research Designs}

The design for this study is a cross sectional descriptive survey design. The use of a descriptive design was found to be appropriate as a descriptive research methodology has to do with existing conditions and relationships, (NOUN, 2004). The primary purpose of this study is to determine if there is a relationship between BMI, gender, and academic achievement of students. This design is suitable for the study as it examined the existing BMI of the students and its relationship with gender and the academic achievement of the students.

\section{Population and Sample}

The study population consists of students from state and private secondary schools in the Owerri Education Zone, distributed in 11 LGAs in Imo State with a population of 23,229 students (Imo State Schools Management Board, (2018/2019 record). A sample of five schools which includes;

Orogwe Secondary School, New Leatre Secondary School, Enyiogugu Secondary School, Bright International Secondary School and Urban Secondary School were randomly selected. A sample of 24 students each, 12 males and 12 females were purposively sampled from each of the sampled schools to arrive at an equal number of males and females giving a total of 120 students from the sampled schools.

\section{Instruments for Data Collection}

The instruments used for data collection were structured students Test Question (SSTQ) and their school-based result for the last term in English, Mathematics, and Basic Science. The choice of the 3 subjects is because of the fact that these are the core subjects that are also compulsory at Junior secondary certificate examination. SSTQ was developed as an achievement test, covering the 3 major junior secondary school subjects of English, Mathematics and Basic Science. The test was multiple choice questions, drawn from J.S.S. curriculum and consisted of 20 questions each from each of the 3 subjects with 4 possible options to choose from. The reliability of the instrument was measured using Cronbach Alpha and a reliability coefficient value of 0.82

\section{Procedure of Data Analysis}

The weights of the students were individually measured using a portable mechanical bathroom weighing scale in $\mathrm{kg}$. Measurement of height was done using a vertical wooden measuring rule calibrated in metres. The BMI of each participant was obtained from the calculation of each of their weight measured in $(\mathrm{kg})$ by their height $\left(\mathrm{m}^{2}\right)$. From the calculation, each participant was classified as either, underweight, normal/healthy weight, overweight, or obese in line with WHO (2006) body mass classification chart for adolescents aged between 10-14 years. The test was then administered with the help of form teacher in the schools. The tests were marked and recorded. The last session cumulative scores were taken in each of the 3 subjects for each of the students, 
Journal of Educational Research in Developing Areas (JEREDA)

Vol. 2. Issue 2, Pp. 164-172, 2021

http: / / www.jeredajournal.com

E-mail: info@jeredajournal.com

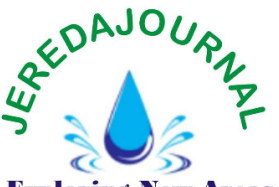

and an average was taken for each of the subjects for each student. This was to ensure the students' ability was fully taken into consideration.

\section{Method of Data Analysis \\ Data collected were analyzed using mean difference and Standard Deviation for research questions and $\mathrm{T}$ - test for analysis of hypothesis.}

RESULTS

Research Question 1: What is the difference in the mean academic achievement scores of male and female students in English, Mathematics and Basic Science in Owerri education zone?

Table 1: Table showing the mean and standard deviation of students based on gender

\begin{tabular}{llllll}
\hline & Gender & N & Mean & STD & $\begin{array}{l}\text { STD Mean } \\
\text { Error }\end{array}$ \\
\hline Score & Female & 60 & 49.52 & 20.570 & 3.694 \\
& Male & 60 & 49.43 & 21.728 & 3.967 \\
\hline
\end{tabular}

The result in table 1 shows that male students had a mean of 49.5 and standard deviation of 20.570. While the female students had a mean of 49.4 and standard deviation of 21.7 given a mean difference of 0.09 in favour of female students
Research Question 2: What is the difference in the mean achievement scores of students based on their BMI Index?

Table 2: Difference in the mean academic achievement scores of students based on their BMI.

\begin{tabular}{clllll}
\hline BMI & & N & Mean & S.D & $\begin{array}{l}\text { STD Error } \\
\text { Mean }\end{array}$ \\
\hline Scores & $\begin{array}{l}\text { Below 18.5 } \\
\text { Underweight }\end{array}$ & 90 & 45.09 & 18.127 & 2.673 \\
& $\begin{array}{l}\text { 18.5-24.9 } \\
\text { Normal }\end{array}$ & 30 & 62.93 & 23.900 & 6.171 \\
\hline
\end{tabular}

The result in Table 2 shows that the underweight $(<18.5)$ students had a mean of 45.1 with a standard deviation of 18.1. While normal weight (18.5 24.9), students had a mean of 62.9 with Standard Deviation of 23.9 given a mean difference of 17.8 in favour of the normal weight students.

Hypothesis 1: There is no significant difference in the mean achievement scores of male and female students. 
Journal of Educational Research in Developing Areas (JEREDA)

Vol. 2. Issue 2, Pp. 164-172, 2021

http://www.jeredajournal.com

E-mail: info@jeredajournal.com

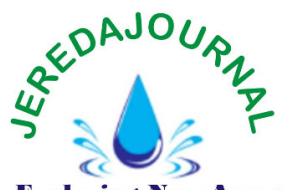

Exploring New Areas

Table 3: T-Test analysis on difference in the mean achievement scores of male and female students

\begin{tabular}{|c|c|c|c|c|c|c|}
\hline & & $\mathbf{F}$ & Sig & $\mathbf{t}$ & dt & $\begin{array}{l}\text { Sig } \\
\text { (2-tailed) }\end{array}$ \\
\hline \multirow[t]{2}{*}{ Scores } & $\begin{array}{l}\text { Equal variance } \\
\text { Assumed }\end{array}$ & .019 & .892 & .015 & 119 & .988 \\
\hline & $\begin{array}{l}\text { Equal variance } \\
\text { Not assumed }\end{array}$ & & & .015 & 119 & .988 \\
\hline
\end{tabular}

From the t-test in table 3 , the statement of hypothesis one is accepted, implying that there is no significant difference in the mean achievement scores of male and female students. This is because the $\mathrm{p}$-value ( $\mathrm{Sig}=.988$ ) is greater thanthe 0.05 alpha level.
Hypothesis 2: There is no significant difference in the mean achievement scores of students based on their BMI Index.

Table 4: Analysis of the $T$ test of the difference in the mean achievement scores of the students based on their BMI.

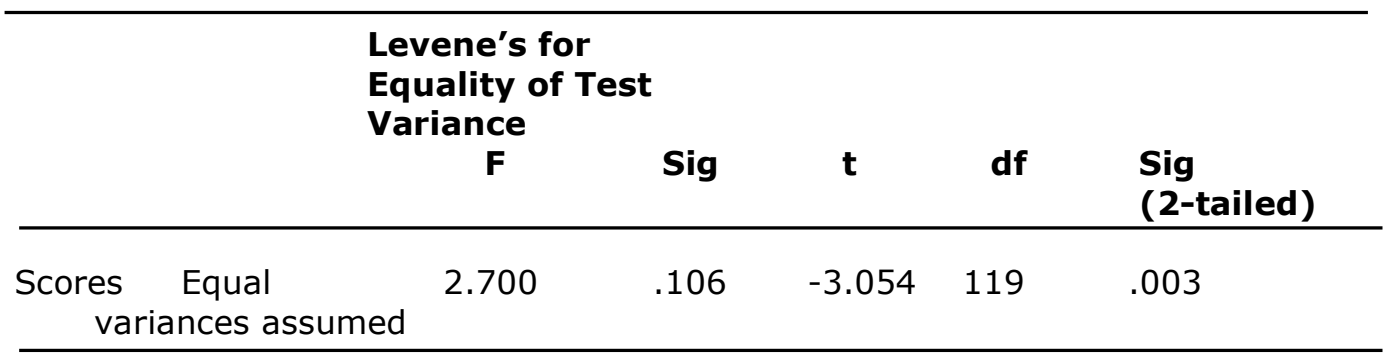

From the t-test analysis shown in table 4, the statement of hypotheses two is rejected, implying that there is a significant difference in the mean achievement scores of students based on their BMI Index. This is because the Pvalue ( $\mathrm{Sig}=0.003$ ) is less than 0.05 alpha level.

\section{DISCUSSION}

In this study, $64 \%$ of the students had a BMI less than $18.5 \mathrm{~kg} / \mathrm{m}^{2}$ which places majority of the study population in the underweight fraction, $29.6 \%$ were normal weight while $6.4 \%$ were overweight. The disparity between the prevailing BMI in the study (underweight) and the normal BMI (normal weight) is in a ratio of $2: 1$. This contradicts the findings of Alswat, Al-shehri, Aljuaid,
Alzaidi and Alasmari, (2017), where $24.5 \%$ were either overweight or obese. The result revealed that gender has no significant effect on academic performance of students. This implies that being male or female has no significant effect on a student's academic performance and therefore not an important variable in academic performance. Other variables, such as BMI, have an important impact on academic performance. This result is in agreement with the findings of Unamba, Onyekwere and Ihekwaba (2015) who found no significant difference in gender achievement using activity-based learning strategy. Also Nwaiwu and Audu (2005) in their work influencing factors in female Engineering and Technical Education in Nigeria and Lorchugh, 
Journal of Educational Research in Developing Areas (JEREDA)

Vol. 2. Issue 2, Pp. 164-172, 2021

http://www.jeredajournal.com

E-mail: info@jeredajournal.com

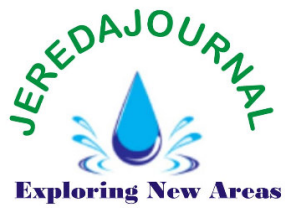

(2006) in, influence of cognitive styles, cognitive level and gender on students' achievement in Physics, found no significant difference in achievement among gender. Also these findings are in conflict with that of Onyekwere, Okezie, Ezeribe and Unamba (2018) who found out that there is significant difference between male and female students in mathematics.

Also revealed in this study is that BMI has a significant effect on academic performance of students. This finding is in line with that of Yadav and Choubey (2014), which revealed that academic achievement of adolescent girls whose BMI is in normal range was significantly higher as compared to academic achievement of students who are either under weight or overweight, respectively. This finding is also in conflict with that of Suleiman, Eze and Karimah (2017) who concluded that there was no association between BMI and academic performance.

\section{CONCLUSION}

Based on the findings of this study, the following conclusions were made:

1. Gender has no significant effect on academic performance of students in English, Mathematics and Basic Science. This means that the academic performance of students in the said subjects is irrespective of gender.

2. BMI has a significant effect on academic performance of students.

BMI from the result showed a significant effect on academic performance. This goes to show, that the nutritional status of a student is an important variable in school outcome. A hungry/malnourished student may not be able to have a full brain capacity to process information and achieve learning. The result obtained showed that the collected data recorded an insignificant number of overweight students in the schools sampled and more of normal weight and underweight. This is a reflection on the general standard of living in Nigeria, which has resulted in a higher number of malnourished children.

\section{RECOMMENDATIONS}

The following recommendations were made based on the research findings

1. Students from different BMI range may exhibit different needs, characteristics and attitudes for learning. Thus, instructional design that can successfully transmit crucial learning skills and knowledge to students from different BMI range should be put in place.

2. Parents should give their children a balanced diet to overcome the consequences of malnutrition that is overweight or underweight.

3. Seminars should be organized at state levels, education zones and ministries of education where teachers, parents and curriculum planners will be taught various ways of teaching the underweight students so as to boost and improve their performance.

4. Underweight students should be counseled on how to improve their weight so as to avoid dropping down to severe underweight.

The government should introduce school programs such as games, school feeding, parental/guardian counseling towards achieving a healthy weight amongst school children so as to avert a global educational and health tragedy by such a hidden monster: the abnormal BMI pattern.

\section{Conflict of Interest}

The authors declare that they have no conflict of interest.

Notes on the Authors:

Ofoego Chinyere is a Chief Lecturer at the Department of Educational Foundations and Administration with a Ph.D. and M.Sc. in Philosophy of Education.

Ukogo Ifeoma is a Lecturer in the Department of Integrated Science, with a M.Sc. in Environmental Health Biology and a PGDE. She's currently pursuing a PhD programme in Environmental Microbiology. 
Journal of Educational Research in Developing Areas (JEREDA)

Vol. 2. Issue 2, Pp. 164-172, 2021

http://www.jeredajournal.com

E-mail: info@jeredajournal.com

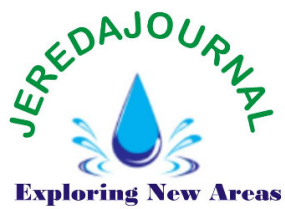

Chinaka Ada Iheoma is a lecturer in the Department of Biology, with an M.Sc. in Environmental Health Biology and is currently pursuing $\mathrm{a} \mathrm{PhD}$ at the University of Nigeria Nsukka.

Nwaeze Esther is a Lecturer in the Department of Integrated Science, with an M.sc in Science Education, B.sc in Integrated Science and an N.C.E in Mathematics/Integrated Science.

Chukwu Hannah lectures in the Department of General Studies, she holds a Bachelors degree in English Education, a Master degree in Linguistics, and is currently pursuing a PhD in English Language.

All the authors lecture in Alvan Ikoku Federal College of Education, Owerri, Nigeria.

\section{Authorship and Level of Contributions}

Ofoego Chinyere handled questionnaire distribution in some of the sample schools, compiled and arranged results collected.

Ukogo Ifeoma thought up the title of the study, designed the study, wrote the introduction, purpose and compiled the manuscript.

Chinaka Ada Iheoma generated the research questions and hypotheses, she did the conclusion and recommendation part.

Nwaeze Esther handled the statistical analysis, data compilation and discussion.

Chukwu Hannah handled questionnaire distribution in some of the sample schools, compiled and arranged results collected and proof read the manuscript.

Disclaimer Statement: We the authors declare that this paper is our collective effort and is drawn from the TETfund sponsored study on "Comparative analysis of Academic Performance and Body Mass Index of J.S.S Students in Owerri Educational zone". All quoted or paraphrased texts are captured in the

body of the work and full details are given in the reference section.

\section{REFERENCES}

Akuezuilo, E.O., \& Agu, N. (2003). Research and statistics in education and social science: Methods and applications. Nuel Centi Publication \& Academic Press Ltd.

Alswat A., A., Al-shehri D. A., Aljuaid A. T., Alzaidi A B.,\& Alasmari D. H., (2017). The association between body mass index and academic performance. Saudi Med. Journal, 38(2), 186-191.

Aniodoh, H.C.O.,\& Eze, G.N. (2014). Enhancing girls' participation in science through feminist pedagogical techniques: $A$ panacea for gap in science and technology classrooms. 55th Annual Conference Processings of Science Teachers Association of Nigeria STAN, Pp. 292-296.

Dike, U.A. (2018). Gender roles, politics and Christian ministry. International Journal of Gender and Development Issues, 1(8), 226-234.

Garcy, A.M. (2009). The longitudinal link between student health and maths achievement scores. Journal of Education for Students placed at Risk, 14(4), 283-310. Doi.10.1080/1082466090344875 5.

Gray, D.S., \& Fujioka, K. (1991).Use of relative and body mass index for the determination of adiposity. Journal of Clinical Epidemology, 44 (66), 545-550.

Lorchugh, A.S. (2018). Influence of cognitive styles, cognitive level and gender on students' achievement in Physics.Unpublished M.Ed. Project, University of Nigeria, Nsukka.

Ndirika, M. C. (2013). Investigating gender disparity in science enrolment and achievement in Abia State. Towards Achieving the MDG's, 54th Annual 
Journal of Educational Research in Developing Areas (JEREDA)

Vol. 2. Issue 2, Pp. 164-172, 2021

http://www.jeredajournal.com

E-mail: info@jeredajournal.com

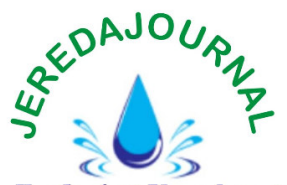

Exploring New Areas

Conference Proceedings of STAN, 292-296.

Nwaiwu, N. E., \& Audu, B. (2005). Influencing factor in female engineering and technical education in Nigeria. Knowledge Review 19(1),3-11.

Organization for Economic Co-operation and Development. (2010). Lessons for PISA for the United States. Retrieved from http://www.oecd.org/pisa/46623 978.pdf

Onyekwere, N. A., Okezie, N. N., Ezeribe, S.N., \& Unamba, E.C. (2018).Gender and cognitive styles on students' academic achievement

Mathematics.International

Journal of Gender and

Development Issues, I(8), 358367.

Simpson, J.A., \& Weiner, E.S.C. (1989). The oxford English dictionary (2nd ed.) vol. 1. Clarendon Press.

Suleiman, J. B., Eze, E.D., Karimah, M.R., \& Iliya, E. (2017).International Journal of Brain and Cognitive Sciences, 6(4), 65-70.

Sumerall, K.V. (2014). Physical fitness and body mass index as predictors of academic achievement. Honors Theses 270. http://aquila.usm.edu/honor $\mathrm{s}$ theses/270.

Unamba, E. C., Onyekwere, N. A., \& Ihekwaba, C.M. (2016). impact of activity-based learning on pupils level of cognitive attainment in geometry. Journal of Pristine 12(1), 235-248.

Yadav, R.A., \& Choubey J.B. (2014). Effect of socioeconomic status on body mass index and academic performance of college going girls. Indian Journal of Science Research, 9(1), 145-1. 